Please do not remove this page

RMIT

UNIVERSITY

\title{
Redressing gendered undervaluation in New Zealand aged care: Institutions, activism and coalitions
}

Charlesworth, Sara; Heap, Lisa

https://researchrepository.rmit.edu.au/esploro/outputs/9921908998401341/filesAndLinks?institution=61RMIT_INST\&index=null

Charlesworth, S., \& Heap, L. (2020). Redressing gendered undervaluation in New Zealand aged care:

Institutions, activism and coalitions. Journal of Industrial Relations, 62(4), 608-629.

https://doi.org/10.1177/0022185620925102

Document Version: Accepted Manuscript

Published Version: https://doi.org/10.1177/0022185620925102

Repository homepage: https://researchrepository.rmit.edu.au

CC BY-NC-ND V4.0

(C) Australian Labour and Employment Relations Association (ALERA) 2020

Downloaded On 2023/04/26 23:46:47 +1000 


\title{
Pre-print of:
}

\section{Charlesworth S \& Heap L (2020). Redressing gendered undervaluation in New Zealand aged care: Institutions, activism and coalitions Journal of Industrial Relations, 62, $608-629$.}

\begin{abstract}
This article explores the apparent conundrum of how, with minimal employment standards and limited equal pay laws, New Zealand managed to significantly redress the gendered undervaluation of lowpaid aged care work. To draw out the pathways to these reforms, we focus on the long-term strategic coalitions that underpinned them. We examine, in particular, the activism of a diverse range of policy actors - unions, employers, industrial and human rights bodies and civil society groups, which together have worked to 'undo' the limitations of equal pay and employment regulation. Our findings point to the benefits of strategic collaboration between policy actors in New Zealand and an approach which recognises the intersection of unequal pay with other gendered dimensions of disadvantage in aged care work. Different strategies used over time by diverse actors helped them overcome inadequate industrial and equal pay infrastructure to realise meaningful increases in hourly rates of pay, buttressed by improved working time arrangements and provision for career progression. We conclude by highlighting some lessons for institutional and policy actors in other national settings drawn from the New Zealand collaborative approach to equal pay in care work.
\end{abstract}

\section{Keywords}

Aged care, equal pay, gender undervaluation, New Zealand, strategic coalitions

\section{Introduction}

As in other developed economies, the long-term care (LTC) sector in New Zealand has been marked by a systemic and gendered undervaluation of the work underpinned by inadequate government funding and reflected in persistently low wages and poor working conditions. In New Zealand, the Ministry of Health directly funds both 
for-profit and not-for profit service providers through a network of District Health Boards to provide residential and community- or home-based support services. The vast majority of the workers employed by service providers are non-professional frontline workers who undertake most of the direct care of service users.

Within this context, the 2017 equal pay settlement in the New Zealand aged care sector has been hailed as a landmark achievement with widespread implications not only for other low-paid feminised sectors in New Zealand but also internationally (Pennington, 2019; Campbell, 2019). The settlement included government funding for significant wage increases for frontline aged care workers in residential care and in community-based care. Crucially, it was directly linked with associated improvements in working time arrangements so essential to realising substantive equal pay. Indeed, a key critique of the international focus on closing the 'gender pay gap' lies in its narrow focus on comparing female and male rates of pay to the exclusion of other employment regulation, sectoral conditions and work organisation that can structure, limit and fracture working hours with direct consequences for income security (see Hebson and Rubery, 2018; Milner, 2018; Charlesworth and Smith, 2018).

The details of the legal case that contributed to the equal pay 
settlement are set out in this issue (see Parker and Donnelley this issue). The equal pay settlement, which was estimated to cost some 2.048 billion dollars, provided significant wage increases to some 55,000 low-paid frontline aged and other care workers with a fourstep pay classification structure pinned to the achievement of designated certificate qualifications. It is worth noting briefly however some key features of two related government funded agreements that preceded the final 2017 equal pay settlement, which also emerged out of the collaborative activism detailed in this paper. The 2014 travel time settlement and the 2016 guaranteed hours settlement both go some significant way to address the gendered working time inequality that has long been a feature of frontline aged care work not only in New Zealand but internationally (Charlesworth, 2017).

The travel time settlement followed a Human Rights Commission inquiry into aged care (NZHRC 2012) which had raised the significant issue, faced in many countries, of home care workers not being paid for the time they spent travelling between clients. In 2014, following legal claims made by unions on behalf of their members, the Government agreed that such travel was indeed work and in a 'between travel' settlement between the government, unions and home care employers provided additional funding of some 
NZ\$36.2 million in 2015/2016 and \$38.6 million in 2016/17 to the home care sector to meet the cost of providing for workers' travel time and associated fuel costs (Ministry of Health, 2014).

This agreement, which was passed into legislation in 2016, the Home and Community Support (Payment for Travel Between Clients) Settlement Act 2016, and the additional government funding attached to its realisation, provided the impetus for a further consent settlement between unions, employers and the government on 'regularising' the hours of the aged care workforce. Until this point, many home support aged care workers had worked irregular on demand hours, being paid per client visit, with residential care workers also not having any enforceable rights to regular shifts. In 2014, a settlement was agreed to provide for guaranteed minimum daily and weekly hours, through a range of mechanisms, which was also supported by specific government funding for unfilled guaranteed hours (Ministry of Health, 2017). Estimated to cost $\$ 1$ million in initial implementation costs, the establishment of guaranteed hours via the Employment Standards Legislation Act 2016 also expressly includes meeting the costs of client cancelled visits and provides an 'availability allowance' where workers are required to be available for work that they do not perform., with additional funding provided for this purpose. 
What appears extraordinary in the first instance about this multi-layered equal pay settlement is that it was accomplished in the face of what could only be described as 'bare bones' employment regulation and limited equal pay legislation underpinned by outdated definitions and concepts. While the genesis and indeed the limited impact of the Equal Pay Act 1972 (EPA), and more broadly New Zealand's response to ILO 100, is detailed elsewhere in this issue (see Parker and Donnelly this issue) we briefly outline here the context of stripped back employment standards in which the package of aged care equal pay outcomes was achieved in New Zealand.

Together with Australia, New Zealand had historically enjoyed a reputation for robust employment standards. However, the introduction of the Employment Contracts Act 1991 (ECA) by the National government abolished the awards system, severely restricted trade union action and introduced individual contracts with very limited enterprise bargaining (Campbell, 2019: 93-94). Workers, including aged care workers, were left with only very basic statutory protections including a minimum wage and limited paid leave with few working time rights. Not surprisingly there was a dramatic reduction in union density and influence with minimal enforcement of the few remaining statutory rights. The introduction of the Employment Relations Act 2000 (ERA) improved the basic 
statutory rights to a limited degree by increasing the minimum wage and improving annual leave entitlements. In 2008, however, the incoming National government reversed some of these small gains (Foster and Rasmussen 2017), leaving a growing group of New Zealand workers in insecure work with casualised work practices found even in permanent employment (NZCTU, 2013; Campbell, 2019: 96).

So the question we respond to in this paper is how, despite inadequate equal pay regulation and few regulatory options to address low paid work, did New Zealand achieve such significant pay and working time outcomes for aged care workers and also generate a new movement for equal pay? The New Zealand Human Rights Commission [NZHRC] embarked on an inquiry into the aged care sector in 2011/2012, (the Caring Counts Inquiry), driven by concerns about the impact of insecure work on both aged care workers and the vulnerable older people to whom they provided care. The Commission's report detailed the low pay and the poor working conditions for workers in the feminised aged care sector finding that many frontline workers were paid at rates close to the then minimum wage of $\$ 13.50$ per hour, the inadequacy of the rate exacerbated by the insecure working time arrangements common across the sector. The lack of recognition of travel time between clients as 'work' time 
was also found to be a significant issue for home care workers (NZHRC, 2012). The NZHRC report provided a significant impetus to the regulatory reform in aged care detailed above. However, it was not the only catalyst.

In our analysis we draw on a number of primary and secondary sources including government policy and government agency documents, documents produced by the various individuals, organisations and coalitions that coalesced around the struggle for equal pay in aged care, interviews with several of the major policy actors and government documentation on the equal pay settlement and associated improvements in working time provisions. The next section sets out the key framings we employ in our analysis, with the following section exploring the institutional context and the diverse coalitions that formed around the struggle in relation to the frontline work undertaken in the aged care sector as well as for equal pay more broadly. We conclude by highlighting key lessons for institutional and policy actors in other national settings drawn from the New Zealand's collaborative and multi-dimensional approach to action on equal pay in care work.

\section{Framings}

In our analysis of the struggle for equal pay in aged care in New Zealand we draw firstly on insights from new institutionalism (Krook and Mackay, 2011; Mackay, 2014; Macdonald and Charlesworth, 
2018) to explore the ways in which the comparatively poor New Zealand equal pay and labour law infrastructure opened up possibilities for action by a diverse range of strategic coalitions to achieve equal pay outcomes in aged care that have eluded systems with more robust equal pay architecture.

New institutionalism, which takes a broad understanding of institutions as constituted not only by formal institutions but also by norms, values and ideas and incentive systems, has been concerned in the main with institutional continuity and change and with how institutions structure political and social life (Lovenduski, 2011; Krook and Mackay, 2011). More recently, feminist new intuitionalism has drawn attention to the gendered character of institutions and their 'gendering effects' (Mackay, 2011: 181). Feminist new institutionalism (NI) not only recognises that the formal and informal 'rules of the game' profoundly shape political life but also that political institutions, such as those that constitute the employment and care 'regimes' at issue in this paper, are 'inescapably gendered' (Mackay, 2011: 181). By 'regime' we draw on a social policy conception similar to the 'rules of the game' embedded in NI. A regime includes 'the policies, practices, legacies, discourses, social relations and forms of contestation' relevant to the particular regime in question (Williams, 2012: 371). In feminist NI, attention is paid to the 
gendering nature and the gendering of institutions and, critically, to the gender norms constraining change in these institutions (Mackay, Kenny and Chappell, 2010; Mackay, 2011).

In reflecting on the struggle for, and at least a partial settlement of, equal pay for work of equal value for aged care workers in New Zealand, feminist NI provides a useful analytical lens. Firstly, it provides a space to acknowledge the convergence and gendering of the employment and the care regimes or institutions, (see Krook and Mackay, 2011: 16), In particular, a feminist NI framing allows us to highlight the continuity and change in the institutional context within which a diverse range of policy actors took action over many years and the ways in which the interests of those policy actors have also converged and diverged, at different point in time. Secondly, feminist NI provides a way of identifying the gender discourses employed at different times by the different actors, including the ways in which these discourses may 'enable gendered policy change, but also constrain its form, content, and impact' (Krook and Mackay, 2011: 15). The NI concept of 'nested newness' also provides a useful lens on the emerging implementation constraints of the New Zealand pay equity settlement and the ways in which old gendered legacies can work to limit the extent of gender reforms that challenge those legacies (Mackay, 2014: 553; Macdonald and Charlesworth, 2018: 
448).

Our analysis is also informed by the different ways in which gender equality approaches and discourses, including to equal pay, have been categorised by a number of key gender equality scholars. Legal feminist scholars Fredman and Goldblatt, for example, distinguish between substantive gender equality and formal gender equality, which, in essence, is based on the principle of symmetrical equal treatment, treating 'like for like', a principle which may in fact ignore and entrench the systemic disadvantage experienced by women (Fredman and Goldblatt, 2015: 1). They argue that a more substantive and multi-dimensional understanding of gender equality would focus on redressing the disadvantage associated with gender; recognise the central role of dignity and the need to address stigma, prejudice, humiliation and violence; be transformative, with a consequent redistribution of power and resources and a structural change in the institutions that perpetuate women's disadvantage; and ensure real voice, that is equal participation both socially and politically (Fredman and Goldblatt, 2015: 1-2). Walby distinguishes more sharply between three major approaches to gender equality: 'equality through sameness (equal opportunities or equal treatment), through equal valuation of difference (special programs), and the transformation of gendered practices and standards of evaluation 
(Walby, 2005a). She suggests that underlying the typical distinctions made in such models lies both a vision of the 'gender-equal world' and the strategies and tactics to get there (Walby, 2005b: 325).

Insights from feminist NI together with attention to different framings of gender (in)equality, can be applied, we suggest, to the equal pay discourses employed by the various policy actors in New Zealand and, in particular to identify the extent to which discourses invoked in their activism recognise the intersection of unequal pay with other gendered dimensions of disadvantage in aged care work.

To draw out the common interests and deep community engagement that shaped the broader public awareness of the issue of unequal pay in aged care, we employ the concepts of community unionism and 'coalition unionism' (Black, 2018; Tattersall, 2008) to provide a frame for our analysis. Definitions of community unionism have varied because of the different ways in which 'community' is defined, with one framing seeing it as a 'community-based organisation, formed by people who inhabit a particular geographical space and share a common identity or interest' (Black, 2018: 120). While the focus on common interest is useful here, such framing assumes a tangible community-based partner with whom unions can engage in coalition work (Black, 2018: 121). As we outline below this was not the case in the New Zealand coalition we examine here, 
where the 'community' in community was forged by diverse interests and groups ranging from advocacy groups, women's groups, the Human Rights Commission and indeed employers.

Tattersall suggests, more helpfully for our purposes, that the 'community' in 'community unionism' represents three sets of strategies which extend the definition of community (2008: 417). These strategies comprise: coalition unionism where unions work with community organisations in coalition; a strategy of seeking to organise workers on the basis of common non-workplace identities, interests or place; and place-based organising strategies, which seek to increase a union's impact at a particular scale, from the local to the global (Tattersall, 2008: 418).

Community unionism has also been referred to as 'social movement unionism' a concept developed in the context of the trade union revitalisation debate where social partners have been seen as strategic partners by unions to compensate for the loss of their structural and institutional power (Zajak et al, 2018: 167, Parker, 2011). However social movement unionism typically takes a broader perspective than community unionism focusing more generally on both workers' struggles and wide-ranging social change (Tattersall, 2010: 393). There is also a greater focus on more instrumental and strategic union attempts to gain or retain political and institutional 
influence. The case we are examining here is more a form of community unionism, where multiple, sometimes overlapping, interests have been in play over time not only between unions but also between and within different groups, including institutional policy actors such as the Human Rights Commission.

What makes some community union coalitions more successful than others? As a precursor to successful community-union campaigns, union involvement in community organising is seen as a crucial key to success (Black, 2018; Parker, 2011). Indeed, where the political climate is a hostile one or where some community alliances are unformed and disparate, unions typically need to take a leading role in the campaign effort (Tattersall, 2018). Both political opportunities in internal and external institutional conditions as well as strategic opportunities that are generated around the common interest or concern are crucial to success - in our case the dire state of both the conditions of care and the conditions of work provided in the aged care sector (Black, 2018). In their most positive form, community union coalitions can 'bring out the best in community organisations and unions, mobilising complementary resources to launch campaigns capable of confronting the neoliberal agenda' (Black, 2018: 120). It is worth noting that this broad understanding of community union coalitions does not imply a fixed aggregation or 
indeed a formal structure for decision-making. As Tattersall points out, such coalitions take various forms and unions make strategic decisions at different points in time whether to engage with particular partners and the degree to which they engage with them over particular concerns (2018: 71).

Parker's 2011 analysis highlights the particular spatial aspect of community unionism in the New Zealand context. As we argue below, its small size helps in explaining both inter-union cooperation as well as union coalitions with community groups, employers and government agencies. The material disadvantages of New Zealand's small country setting, particularly in terms of resource levels, also has significant advantages (Parker, 2011: 399-401).

Tattersall argues that shared identity and shared strategic goals are important in all forms of community unionism, but that they will be so to varying degrees under different circumstances (2008: 415). Our assessment attempts to draw out the extent to which shared identity and strategic goals played a role in the community union activism on which we are focused here.

\section{Changing the rules - institutional disruption and transformation}

The 'Terranova' equal pay decisions, Service and Food Workers Union Nga Ring Tota Inc v Terranova Homes and Care Ltd [2013] and Terranvova Homes \& Care Ltd v Service and Food Workers Union Nga 
Ring Tota Inc [2014]) disrupted the gendered rules that governed institutional approaches to wages in New Zealand prior to 2015. Prior to these decisions, and since the deregulation of employment institutions as outlined above, wage increases were achievable only through collective bargaining. Within the New Zealand context, this mechanism had delivered little for those with limited industrial power or where government funding controls wage outcomes, such as in aged care.

Previous attempts at addressing equal pay through the EPA provided marginal relief focusing largely on the removal of formal inequality through differentiated wage rates between men and women under awards (Hill, 2013: 15). Further attempts at reviving equal pay through the introduction of the Employment Equity Act 1990 by the Lange Labour Government and the establishment of the Pay Equity Employment Unit in 2004 under the Clarke Labour Government were disbanded and reversed by incoming National governments (McGregor and Davies, 2019).

Against this background, we suggest in this article that several interrelated factors combined to create the climate within which a historic outcome for one group of workers has led to large scale institutional change. These factors include: the use of strategic litigation and sustained engagement with the aged care sector by the 
Services and Food Worker's Union (SFWU, subsequently Etū); the advocacy of the NZHRC; and the ongoing lobbying for equal pay of feminist activists and organisations from both within and outside of the trade union movement.

Strategic and sustained union action

The success of the SFWU in the Terranova litigation was due not only to its preparedness to undertake an untested innovative legal approach but also to its recognised standing in the industry and the alliances it had created due to its sustained activism. The Union used this standing and worked with employer and aged care advocates over time to advance and defend the rights of workers in residential aged care and to advocate for improved care standards. This 'positive sum' (Tattersall, 2010) form of alliance-building across decades contributed directly to the wide-reaching pay equity and working time settlement in aged care.

According to John Ryall, the long-standing SFWU Assistant Secretary, in an affidavit prepared for the Terranova appeal made available to the authors, the union has been active in organising and representing workers within the aged care sector since the 1970 s (Ryall, undated). This activity included the establishment and improvement of minimum rights through strategic litigation, participation in government inquiries into the structure and funding of the sector, advocacy regarding skills development and recognition 
and the establishment and maintenance of positive working relationships with the key employer association, the New Zealand Aged Care Association (NZACA). Indeed, it is notable that whilst the NZACA opposed the SFWU application in the Terranova case, it did so not on the basis that the workers did not deserve a wage increase, but that contractual and funding arrangements with government hamstrung the ability of aged care employers to pay those increases (NZACA, 2017).

The efforts of the SFWU occurred against a backdrop of the transfer of the responsibility for aged care from the public health system to the community and private sector and the significant diminution in workers' rights after the introduction of the ECA in 1991. Key to the achievement of the aged care pay equity settlement has been the union's preparedness to use all institutional levers available to it including: litigation; lobbying; coalition and alliance building; the media; and pragmatic negotiation.

In the 1970s and 1980s the SFWU's litigation strategy was characterised by an equal opportunity or formal equality approach, with an emphasis on winning parity for aged care workers with those doing the same work in the health system and on advocating for a recognition of the skills of the workers in rest homes.

According to John Ryall, in 1973 the Union established the 
Canterbury Rest Homes' Employees Award, which led to a national rest home award in 1980 (John Ryall, undated). The union subsequently sought to enforce the award wage rates through litigation claiming underpayment and seeking increases in award rates based on parity with public sector hospital rates of pay. Hyman's analysis suggests the limits of this approach. She argues that seeking parity with caring work in the public sector takes up only 'the very direct inequity of lack of equal pay for almost identical work' and fails to tackle the overall undervaluation of caring work (2015: 9).

These cases resulted in increases in wage rates still short of parity, and the introduction of a skills margin linked to the completion of certified training courses developed by the Residential Care Association (a predecessor of the NZACA). In 1987 strike action to achieve parity was taken using the provisions of the new Labour Relations Act 1987 introduced by the Labour government.. However, the strike action was met by fierce opposition and litigation by employers who opposed the public sector comparison. The negotiated outcome resulted in wage increases that still sat below private and public sector hospital counterparts.

Organising aged care workers was another strategy employed by the SFWU which built its standing in the sector. Adopting the 'organising model' used in the United States and elsewhere where 
unions seek to empower workers to find collective solutions to work related concerns (Oxenbridge, 2003), the SFWU set up workplace union delegate structures, members meetings and developed action committees designed to pressure employers for wage increases.

The SFWU ultimately went beyond a typical industrial focus on wage increases and over several years demonstrated its growing grasp of the gendered undervaluation of aged care work and its capacity to harness broader community interest in the quality of aged care services. The Union focused action on sector training and collaborated with employers to develop a two-level qualification through Polytechnics. This pressure for recognition of the skilled nature of aged care work, including through training, together with growing public consciousness about care standards, resulted in the Old People's Homes Regulations 1987, with associated funding to develop training for workers (Ryall, undated). In 1989 a Rest Homes Training Advisory Committee was established with representation from the SFWU as well as government, employer and community organisations.

The radical deregulation of labour relations in New Zealand following the ECA resulted in stagnation in rest home pay rates and loss of conditions including the removal of weekend penalty rates, renegotiated hours, reduced sick leave provisions, and the loss of the 
qualification payment. The significant impact of deregulation in this sector mirrored the disadvantage documented in other femaledominated sectors (Hammond and Harbridge, 1995).

In this environment the futility of bargaining became apparent and resulted in a shift in union strategy post 2000. The SFWU reframed the issue of wages in aged care as one of low pay and poverty for women. As John Ryall describes it, 'We were particularly conscious of what we thought of as gender-based poverty of the women workers in the sector' (Interview 13 December 2016). With limited industrial options or strength, the Union targeted government funding as a way to advance worker rights and pay.

SFWU action during this period also involved sustained coalitionbuilding together with the New Zealand Council of Trade Unions (NZCTU), the national peak union body, and sector unions, including the Public Service Association (PSA). The PSA represents workers in the public and community sectors and is one of the main unions covering home support workers. The SFWU and its coalition partners pressured the Labour government in respect of wages and conditions, skills recognition, training and development of industry standards. Throughout the period the SFWU and the PSA were able to use these coalitions to engage families and communities and political lobby groups around both exploitative wages and quality of care issues. 
Lobby groups included those concerned with the rights of service users and their families such as Grey Power, a charitable organisation those over 65 years, Age Concern, an older persons' advocacy group, and Disabled Person's Assembly, a national organisation for people with disabilities. The unions also engaged employers through common concerns regarding the links between high turnover of staff, low wages and poor conditions and the quality of care (NZACA, 2017; NZHCHA Interview 29 November 2016).

The union alliance via the NZCTU engaged the then Labour government around safe staffing levels, and tying increases in funding directly to the employer provision of higher wages for workers. Additional funding was secured but the concept of a tied funding model was subsequently challenged by employer organisations and declared unlawful by the High Court in 2007 (Healthcare Providers New Zealand Incorporated and Anor v DHBS). As a result, the increased funding was not fully delivered to workers as pay rises and unioninitiated bargaining to deliver the flow-on had limited success (Ryall, undated).

The election of the National government in 2008 meant Labour government commitments to additional funding and the further development of skills and qualifications frameworks were not realised. The SFWU, in conjunction with others, such as the PSA and 
Nurses Union (NZNO), once again embarked on strategic litigation to advance workers' rights. Strategic litigation (Fuchs, 2013) involves taking cases on behalf of individuals to establish a legal precedent and then negotiating settlements applicable across the workforce. As aged care wages and conditions are dependent on government funding, the SFWU began to directly involve the New Zealand government in negotiations. In this strategy, the Union and employer interests were at least partially aligned in shared concerns about the links between poor work conditions and high staff turnover, and the relationships established over decades served all parties well. Two legal claims were of significance in building momentum towards the Terranova litigation and the ultimate aged care settlement. Firstly, the categorisation of 'sleepover' as work and the payment of an hourly rate for care-givers engaged in sleepover arrangements in the disability sector was won in 2011 (Idea Services Ltd v Dickson). In 2013 a union claim that the time home care employees spend travelling between clients is work for the purposes of the Minimum Wage Act 1983 was made to the Employment Relations Authority. ${ }^{\mathrm{i}}$. Both of these cases were part of a concerted and coordinated push by the unions to substantially lift the wages of care and support workers in New Zealand (PSA and E tū, 2008). 
The SFWU decision to litigate the Terranova matter was informed by both the NZHRC 2011-2012 aged care inquiry and by work undertaken by the PSA in relation to the valuing of care work. Exemplifying a difference approach to gender equality, the PSA commissioned a gender-neutral job evaluation exercise that compared the work of community support (home care) workers to therapy assistants in the health sector and the male-dominated corrections officer occupation. This evaluation found the positions were comparable and determined a substantial pay gap existed to the detriment of the community support workers (PSA, 2008). According to John Ryall (undated), the Terranova litigation was also modelled on the community sector equal remuneration decisions of the Queensland Industrial Relations Commission (QSUv QCCI and Others) and the Australian Fair Work Commission (Equal Remuneration Case) (see also Smith and Whitehouse this issue).

The Terranova claim represented a push to significantly disrupt the low wage/ low funding paradigm that had trapped these workers. In its case, the SFWU brought together themes of the value of the work, low wages, poverty and skills recognition with the theme of systemic historical gender-based undervaluation of care work that the Australian cases had identified. At the same time both the SFWU and the PSA, who supported the SFWU given the potential benefits of 
the litigation for its members in care work, recognised the limits of relying on a court win to achieve a substantive equal pay settlement, particularly the need to engage the Crown in the process as increases in funding were necessary (PSA Official, Interview 17 October 2016). The success of the SFWU, PSA, and NZNO in negotiating a settlement following the initial phases of the Terranova litigation needs to be considered against a background of strategic decision making, alliance-building and continuous advocacy by the unions. That alliance-building extended to employer groups. While Terranova, Bartlett's employer, was targeted in the initial claim the unions worked hard with a cross-section of employer groups to make clear their mutual interests in a substantial and broad negotiated equal pay settlement tied to additional government funding, that included not only pay increases, but also travel time and the regularisation of hours (PSA official, Interview 17 October 2016).

Prior to 2000 the SFWU had sought to advance pay for aged care workers through arguments of parity (equal pay for equal work) and skills recognition. Post 2000 , particularly post 2008 , the aged care unions better understood the limitations of arguing for a fairer application of the system and moved to a more transformative approach to remedying pay inequality in the aged care sector. The NZHRC provided institutional support for this approach with this 
support cutting both ways. Judy McGregor, the Equal Opportunity Commissioner, who led the NZHRC Caring Counts Inquiry has noted that 'greater mobilisation and visibility of low paid female carers [was] as a result of strategic trade union intervention' (McGregor, 2013: 14).

After the initial Terranova decision (2013), and prior to the ultimate settlement, the aged care unions and the NZCTU, framed the decision as one impacting on all care and support workers regardless of sector, thus mobilising to spread its impact beyond the residential aged care sector. The NZCTU was already playing an active role with community, employers and faith-based organisations as part of a broader social change agenda to alleviate poverty and to secure decent work, such as through the Living Wage movement (Campbell 2019). The development of a community unionism agenda (Tattersall 2008) calling for social change with a broad focus which included, but was not limited to workers interests, commenced under the leadership of NZCTU President Helen Kelly following her election in 2007 (Parker, 2011). It remains the focus today. The NZCTU was therefore well placed to swing this effort behind the equal pay cause and the relationships created through it. The NZCTU took a leadership role on behalf of unions in tripartite negotiations to establish principles for progressing equal pay claims across the economy, that 
followed the Terranova decision. It also played a role in coordinating efforts to educate the union movement and the community about the impact of the decision. Through its Women's Network the CTU established Equal Pay Hubs throughout the country to spread the word around equal pay (NZCTU).

Activist institutions - the Human Rights Commission narrative \& coalition-building

In 2011 the NZHRC used its inquiry powers to commence an investigation of equal employment opportunities within the aged care sector. The terms of reference for the Caring Counts Inquiry included an examination of the regulatory frameworks and their impact on equal opportunities including decent work, workforce supply, skills and training issues, conditions of work and wages including issues concerning equal pay and pay parity (NZHRC, 2012). The human rights approach that underpinned the Inquiry drew on two key rationales. The first was the low pay, undervaluation and pay inequity that characterised aged care work, with the second being the nexus between the value accorded by society to the aged care workforce and the respect and dignity of older people (McGregor, 2013: 95). The Inquiry took place within a context of growing media and community awareness about problems with the provision of aged care for both service users and workers and media reports included accounts of observed abuse (Stuff, 2009). 
The decisions that Equal Opportunity Commissioner Judy McGregor, made with respect to how the Inquiry was conducted were significant in enhancing its impact. Firstly, throughout the Inquiry the data and information gathered was analysed through a human rights lens that took into account the rights of both aged care workers and the older people to whom they provided care with 'a prioritisation of the rights of the most vulnerable where there was a balance of rights involved' (McGregor, 2013: 96). Secondly, McGregor took the unorthodox decision to go undercover as a care worker within the sector and publicly spoke about her experiences during the Inquiry (McGregor, 2013: 96). Her decision to do so was prompted by a challenge from unions and aged care employers that policy makers should not make pronouncements on matters that they had not experienced (McGregor and Davies, 2019: 623) and her direct experience was incorporated into the final report (NZHRC, 2012: 127-128). While there was some journalistic concern about the subterfuge involved, McGregor's personal experience of the work of aged care garnered significant media attention during the Inquiry and following the release of the Inquiry report (McGregor, 2013: 106).

Thirdly, the manner with which the Inquiry was conducted promoted the collection of the stories and voices of older people and care workers, which helped give a face to 'the complex and abstract 
notion of equal pay' (McGregor, 2013: 104). This approach also provided an increased sense of agency by both groups around employment issues and union activism (McGregor, 2013: 103). In particular, McGregor argues that the Inquiry process and the positive public reception of the Caring Counts report 'encouraged and politicised carers to advocate on their own behalf...rather than expert trade union officials or the EEO Commissioner' (McGregor, 2013: 103) The Inquiry emphasis on stories and real people also provided ready-made media-worthy candidates, such as Kristine Bartlett, whose real-life circumstances of living in poverty could not be ignored (NZ Herald, 2013). Bartlett, a residential aged care worker, was a member of the SFWU and her claim for equal pay provided the basis for the Terranova case. Bartlett became the face of the broad campaign for equal pay in aged care, deepening community awareness of sector's poor pay and conditions and garnering significant community support for the reforms that followed.ii

Finally, encouraging the active engagement of key stakeholders in the Inquiry process, including unions, industry bodies, friends and family associations, ministry officials and political lobbying bodies including Grey Power, created opportunities for these groups to hear each other's perspectives and to identify common interests (McGregor, 2013). This sharing of common interests has continued 
through the operation of the Caring Counts Coalition set up under the auspices of the NZHRC to ensure the implementation of the Inquiry report recommendations. This Coalition includes the aged care unions and the NZCTU together with care workers, advocacy groups employers and employer peaks (Blue, 2014). The proactive engagement by the NZHRC in the Coalition continues to make a strong link between the issues of decent work and quality aged care within a human rights context for both workers and aged people in care (Blue, 2014). It remains active today, including in monitoring the implementation of the Equal Pay Settlement (Douglas and Ravenswood, 2019).

Human rights-based inquiries have been a useful mechanism in New Zealand for raising public awareness and understanding about an issue (McGregor and Davies, 2019). The Caring Counts Inquiry was an exemplar of this mechanism with public support enabling equal pay and better working conditions for aged care workers to be leveraged (McGregor, 2013). The Inquiry report set out a clear and substantive road map for change including explicit recognition that achieving equal pay in aged care was more than increased hourly rates. It included travel time as paid work paid time, predictable scheduling including guaranteed hours, cancellation etc., and the development of a career structure with timely access to training and 
qualifications (NZHRC, 2012). The human rights discourses used by McGregor and the NZHRC in the Inquiry process and report, and in media following its release, clearly draw on a transformative approach to equal pay (Walby, 2005b). The Commission also went beyond the Caring Count's report and took direct action in support of its recommendations, intervening to support the plaintiffs in both Terranova proceedings (NZHRC, 2018).

McGregor has noted the 'confluence of factors' that the Caring Counts Inquiry was able to build on, which together made a critical case for addressing the low pay in aged care (McGregor, 2013: 14). These factors included the ageing population, the increasing presence of for-profit companies in aged care and its relationship to government funding. Crucially, the combination of strategic and sustained union interventions described above and the strong activist role adopted by the NZHRC provided both institutions with political legitimacy to advance, from different vantage points, broadly framed equal pay claims for aged care workers.

\section{Women in coalition}

The NZHRC and the union movement activism towards the achievement of the equal pay settlement in aged care also built on significant engagement, both separately and in collaboration, with the women's movement in New Zealand. Indeed, there is a strong history of women's organisations, unions and pay equity organisations 
working together for equal pay over a lengthy period in New Zealand (Hill, 1994; Wilson, 1992; Hyman, 2015; McGregor and Davies, 2019). The PSA, in particular, has invested significant resources to pursue equal pay over more than a century (Martin, Davies and Ross, 2018); Action taken by unions to mobilise around equal pay, have both built on and been enhanced by coalitions bringing together unions, feminist organisations such as the National Council of Women and the Coalition for Equal Value for Equal Pay (CEVEP), with other interested women's organisations. These coalitions include the Pay Equity Challenge Coalition and Pay Equity Coalition Auckland. The Pay Equity Challenge Coalition and CEVEP made submissions in favour of the plaintiffs in the original Terranova matter before the New Zealand Employment Court (Hill, 2013: CEVEP, undated) bringing significant expertise on gender and pay inequality to the proceedings. Organisations such as CEVEP with members who have been actively engaged, including in policy inquiries, legislative reforms and pay equity taskforces, since the 1970s (CEVEP, undated) gives them both authority and political capital in relation to the policy positions they espouse.

The individual member organisations of these coalitions and the coalitions themselves act both independently and in coordination. Their existence and the actions of legacy feminist activists has kept 
the issue of pay equity in public discourse over time, including when, following the enactment of the ECA, union capacity to take up these matters was reduced (McGregor and Davies, 2019). Their activism, which also supported local and national actions for equal pay, was also critical to public education about the benefits of the Terranova decision and the policy initiatives flowing from it.

Many of the organisations that make up these coalitions have had feminist unionists in their membership and leadership, who have also been active both within the union movement and also in non-union women's organisations such as the National Council of Women. This overlap is seen in the linkage between women unionists working for equal pay and those engaged in the Living Wage movement. Tensions continue to exist, however, between a union emphasis on engaging and organising, such as through bargaining, and an emphasis by women's groups on mechanisms to support women who are not in unionised sectors to pursue equal pay (Hyman, 2015). Nevertheless, the overlapping interests between unions and women's groups has further enhanced the spread of information and expertise and understandings of the connections between poverty, gender pay discrimination and other forms of discrimination.

The close relationships between union women as members of organisations that are in coalitions with unions and also 
representatives of their own unions appears to be a feature of what Parker (2011) has described as a small country setting. Arguably this particular spatial context has enhanced the relationship between unions, women's groups and other organisations and increased awareness and understanding of mutual interests which may not be possible in a larger national setting.

\section{Conclusion}

Mackay (2014) suggests that restructuring or change within (political) institutions creates an opportunity to embed gender rights and freedoms. The Terranova decisions created the space for a redesign of the architecture for addressing gender pay inequality and for pursuing improvements in pay and conditions more generally in New Zealand. However, it was the sustained activism by diverse and dynamic community union coalitions over many years, together with the strategic intervention of the NZHRC, that created the political and institutional environment necessary to establish new 'rules' around decent work in aged care.

Decades of activism by the SFWU (and others) created not only a consistent narrative about the value of aged care work but also, with the intervention of the NZHRC, made a connection between the industrial and human rights of those workers and the human rights of those they cared for (McGregor, 2013). The diverse coalitions and 
alliances built over this time both drew on and enhanced the standing of the SFWU and the NZHRC and their institutional capacity to leverage community, employer and political support for decent work and improved care standards.

The SFWU's understanding of the problem of pay inequality in frontline aged care work, and its public characterisation of its causes has shifted over time and reflects different approaches to gender equality and to equal pay more particularly. The SFWU has variously understood and used discourses representing the problem as a lack of parity with others doing the same work in different sectors and also as one of undervaluation of skills and the nature of work undertaken. The problem of unequal pay was also characterised as an issue of low pay linked to poverty; and ultimately as an issue of low pay, poverty and systemic gender-based undervaluation. In the end the approach the SFWU employed, creating public awareness of the links between low pay, poverty, discrimination and care conditions, proved to be successful in both generating and building on public and employer support and the political capital to create substantive change. The momentum for change was also created sometimes separately and sometimes in tandem with the conduct and aftermath of NZHRC Inquiry, and the partnerships with advocacy groups, employer groups and in particular the PSA, and the NZCTU. 
The activism of the NZHRC and the linkages that it made between worker's rights and human rights discourses provided institutional support for the union's claims that the work of aged care was both undervalued and that the workers were subjected to gender-based discrimination. This, and the choice by Judy McGregor, the Equal Opportunity Commissioner who conducted the NZHRC inquiry, to showcase the lived experience of the workers, helped to shape broader public awareness of causes and consequences of unequal pay in aged care and the poverty-like conditions in which the workers were living.

The fact that the NZCTU had adopted a broad community unionism approach, and the union movement was already working closely with business, faith and community organisations to alleviate poverty through the Living Wage movement, meant that these relationships could be leveraged in support of equal pay, particularly as a strategy to alleviate poverty for low-paid women. Indeed, as Jill Rubery notes, framing equal pay claims as primarily aimed at helping the low-paid is a particularly effective equal pay strategy in moving claims from technical to political ones (2018: 227). Likewise, the close connections between feminist activists within unions and feminist women's community organisations, a feature of New Zealand's small country context, facilitated mobilisation around equal pay and 
created pressure not only for a political solution for aged care workers but also made equal pay a central issue for unions, business and government.

In reviewing her 2008 model of union-community coalitions, Tattersall suggested two benchmarks of their success (or not): whether partner organisations developed stronger and sustained relationships between them over time; and whether they developed the skills, capacities and talents of their leaders (including everyone from positional leaders to the rank-and-file) (2018: 79). It is clear that the major policy and political actors that formed the diverse coalitions around achieving substantive equal pay in aged care have met both benchmarks of success. Individual actors, such as John Ryall and Judy McGregor, played seminal roles not only in their leadership positions but also in their personal commitment to improve the conditions of aged care workers. There is also evidence for the increasing voice of individual aged care workers and older people through advocacy organisations (McGregor, 2013).

This is not to gloss over the inevitable tensions between unions and employers and indeed the unions and the government that have been present during and since the NZHRC Inquiry and the Terranova decisions. Nor is it to ignore the very real tensions that often exist between human rights and industrial discourses in respect of equal 
pay claims (Rubery and Koukiadaki, 2017). In the case here, however, the industrial discourses employed by the unions intersected with the human rights discourses of the NZHRC. Both took a more holistic view of the claim for equal pay in its specific labour market context and recognised the critical institutional role played by the government as funder. Indeed, the discourses employed by the unions, the NZHRC and women's groups all focused on the structural gendered undervaluation of aged care work and aged care workers, and the role of the government in that undervaluation and on the link between decent work and good quality aged care.

Perhaps not surprisingly there have been some practical implementation issues with several aspects of the negotiated age care settlement(see Douglas and Ravenswood, 2019). In essence, despite the significant additional government funding noted above, parts of the settlement continue to be underfunded in ways that, in effect, continue to construe aged care work as not quite fully 'work' in the full industrial sense (Charlesworth, 2017). The influence of old legacies reflected in gendered norms (McKay, 2014: 553) about the value of aged care work are reflected in the way the government, a key institutional actor, can passively neglect the full implementation of the institutional innovation that is 'equal pay'.

There are lessons for institutional and policy actors in other 
national settings drawn from the New Zealand collaborative approach to equal pay for work of equal value in aged care work. One lesson is the importance of strategic community union coalitions sustained over time around equal pay for work of equal value more generally, as well as in the aged care sector in particular. What is striking about the New Zealand case is the achievement of the aged care settlement in the context of poor equal pay and industrial relations infrastructure, providing evidence of 'hope in a hostile environment' (Tattersall, 2008: 6). This case provides a particular contrast with Australia, where more robust regulatory equal pay scaffolding at the federal level has failed to deliver (Charlesworth and Smith 2018). Despite the poor drafting of the EPA and the radical deregulation of industrial relations since the 1990s, the success of actors involved in the aged care claim has created the space for ongoing action around equal pay more generally, including as an industrial strategy to address the historically poorer conditions in feminised sectors, and to provide a basis for significant legislative amendment to the EPA.

One of the explanations of the positive outcome in New Zealand is the specificity of its small-scale context with overlapping connections between policy actors which both necessitated and facilitated the partnership approach between unions and other policy actors 
including the NZHRC and women's groups. These interconnecting interests around better conditions for low-paid feminised occupations, gave a coherence to the fight for equal pay in aged care that is not present in Australia for example (see Junor et al this issue). One of the most interesting features of the New Zealand case is the activism of the NZHRC. Such activism from a human rights body unfortunately remains an exception in international comparison.

\section{Declaration of conflicting interests}

The author(s) declared no potential conflicts of interest with respect to the research, authorship and/or publication of this article.

\section{Funding}

This paper draws on research conducted as part of two Australian Research Council Discovery grants (DP160100175 and DP170100022).

\section{Notes}

${ }^{i}$ As above, this claim resulted in the adoption of the Home and Community Support (Payment for Travel between Clients) Settlement Act 2016.

ii The community connection with Bartlett and her story was so strong that in 2018 she was named New Zealander of the Year (NZ Awards 2018).

\section{References}

Black S (2018) Community Unionism without the Community? Lessons from Labor-Community Coalitions in the Canadian Child Care Sector. Labor Studies Journal, 43(2), 118-140.

Blue J (2014) 'Caring Counts and Beyond'. Speech at SFWU Central Region Women's Conference, 5 November 2014. Accessed 12 October 2019 at https://www.hrc.co.nz/news/dr-jackie-blue-caring-counts-and-beyond/.

Campbell I (2019) Zero Hours Work Arrangements in New Zealand: Union action, Public Controversy and Two Regulatory Initiatives. In O'Sullivan M, Lavelle J, McMahon J, Ryan L, Murphy C, Turner T and Gunnigle P (eds) Zero Hours and On-call Work in Anglo-Saxon Countries, Springer, Singapore, pp 91-110. 
Campbell I, Macdonald F and Charlesworth S (2019) On-Demand Work in Australia in O'Sullivan M, Lavelle J, McMahon J, Ryan L, Murphy C, Turner $\mathrm{T}$ and Gunnigle P (eds) Zero Hours and On-call Work in Anglo-Saxon Countries, Springer, Singapore, pp 67-90.

Charlesworth S (2017) Partial protection? The regulation of home care workers' working conditions. In Fenwick F and Van Goethem V (eds) Regulating for Equitable and Job-Rich Growth Edward Elgar Publishing, Cheltenham, pp. 125-150.

Charlesworth S and Smith M (2018) Gender pay equity in Stewart A, Stanford J and Hardy T (eds) The wages crisis in Australia: What it is and what to do about it, University of Adelaide Press, Adelaide, pp. 85-101.

Coalition for Equal Value Equal Pay [CEVEP](undated) Kristine Bartlett and Service \& Food Workers Union. Accessed 6 October 2019 at: http://cevepnz.org.nz/What\%27s\%20happening/Bartlett\%20vs\%20Ter ranova.htm

Douglas J and Ravenswood K (2019) The Value of Care: Understanding the impact of the 2017 Pay Equity Settlement on the residential aged care, home and community care and disability support sectors. New Zealand Work Research Institute, Auckland.

Foster B and Rasmussen E (2017) The major parties: National's and labour's employment relations policies. New Zealand Journal of Employment Relations, 42(2), 95.

Fredman S and Goldblatt B (2015) Gender equality and human rights. UN Women, New York.

Fuchs G (2013) Strategic litigation for gender equality in the workplace and legal opportunity structures in four European countries. Canadian Journal of Law \& Society/La Revue Canadienne Droit et Société, 28(2), 189-208.

Hammond S and Harbridge R (1995) Women and enterprise bargaining: the New Zealand experience of labour market deregulation. Journal of Industrial Relations, 37(3), 359-376.

Hebson G and Rubery J (2018) Employment relations and gender equality. The Routledge companion to employment relations, pp. 93-107.

Hill L (1994) Feminism and Unionism in New Zealand Hecate 20(1),124-139.

Hill L (2013) 'Equal Pay for Equal Value: The Case for Care Workers' Women's Studies Journal, 27, 14-31

Hyman P (2015) Is active intervention still needed to improve the position of women in the New Zealand labour market Policy Quarterly, 11(1), 3-10.

Krook M and Mackay F (2011) 'Introduction: Gender, Politics, and Institutions' in Krook M and Mackay F (eds) Gender, politics and institutions: Towards a feminist institutionalism. Springer, pp 1-20.

Lovenduski, J (2011) 'Forward' in Krook M and Mackay F (eds) Gender, politics and institutions: Towards a feminist institutionalism. Springer, pp 181-196.

Macdonald, F and Charlesworth S (2018) Failing to live up to the promise: the politics of equal pay in 'new' workplace and industrial relations institutions. Australian Journal of Political Science, 53(4), 446-462.

Mackay F (2011) Conclusion: Towards a Feminist Institutionalism? In Krook $\mathrm{M}$ and Mackay F (eds) Gender, politics and institutions: Towards a feminist institutionalism. Springer, pp 181-196. 
Mackay F (2014) Nested Newness, Institutional Innovation, and the Gendered Limits of Change. Politics \& Gender 10, 549-571.

Mackay F, Kenny M and Chappell L (2010) New institutionalism through a gender lens: Towards a feminist institutionalism? International Political Science Review, 31(5), 573-588.

McGregor J (2013) 'The human rights framework and equal pay for low paid female carers in New Zealand' New Zealand Journal of Employment Relations, 38(2), 4-16.

McGregor J and Davies S (2019) 'Achieving pay equity: Strategic mobilization for substantive equality in Aotearoa New Zealand' Gender Work and Organisation 26: 619-632

Martin S, Davies K and Ross A (2018) Driving and achieving equal pay: the PSA's insights into its first equal pay settlements Accessed 7 October 2019 at: https://www.psa.org.nz/assets/Uploads/PSA-equal-pay-paperFINAL-Tuesday-27-November2.pdf

Milner S (2019) Gender pay gap reporting regulations: advancing gender equality policy in tough economic times. British Politics, 14(2), 121-140.

Ministry of Health (2014) In-Between Travel Settlement Accessed 6 November 2018 at:

https://www.health.govt.nz/system/files/documents/pages/finalsettlement-agreement-dec14.pdf.

Ministry of Health (2017) Guaranteed Hours Funding Framework Accessed 8 November 2018 at:

https://www.health.govt.nz/system/files/documents/pages/guaranteedhours-funding-framework-october-2017.pdf

New Zealand Council of Trade Unions [NZCTU] (2013) Under pressure: Insecure work in New Zealand, NZCTU, Wellington.

New Zealand Aged Care Association [NZACA] (2017) Submission to the Health Select Committee on the Care and Support Worker (Pay Equity) Settlement Bill. Accessed 2 August 2019 at: https://nzaca.org.nz/assets/Uploads/21ed923364/NZACA-submissionto-pay-equity-bill.pdf.

New Zealand Herald (2013) 'Inside our rest homes: Aged care's low-paid workforce', 27 November 2013. Accessed 13 October 2019 at: https://www.nzherald.co.nz/nz/news/article.cfm?c id=1\&objectid=1116 3293.

New Zealand Human Rights Commission [NZHRC] (2012) Caring Counts Tautiaki tika, Report of the Inquiry into Aged Care Sector, NZH, Wellington

New Zealand Human Rights Commission [NZHRC] (2018) Submission on the Equal Pay Amendment Bill, 28 November 2018. Accessed 13 October 2019 at:

https://www.hrc.co.nz/files/8215/4352/5200/Human_Rights_Commissi on_Submission_on_Equal_Pay_Amendment_Bill.pdf.

Oxenbridge S (2003) 'A story of crisis and change: The Service and Food Workers Union of Aotearoa' in Fairbrother P and Yates C (eds) Trade unions in renewal: A comparative study. Taylor \& Francis.

NZ Awards (2018) Kiwibank New Zealand of the Year Winners 2018. Accessed 21 October 2019 at: https://nzawards.org.nz/awards/new-zealanderyear/2018/. 
Parker J (2011) Reaching out for strength within? 'Social movement unionism' in a small country setting Industrial Relations Journal, 42(4), 392-403.

Pennington, A (2019) Workplace Policy Reform in New Zealand: What are the Lesson for Australia? Centre for the Future Work, The Australia Institute, Canberra.

Public Service Association [PSA] (2008) Community Support Workers: a job evaluation exercise, Accessed 21 October 2019 at:

https://www.nzdsn.org.nz/wpcontent/uploads/2016/03/Disability_support-Business_caseDec 2012.pdf.

Public Service Association [PSA] and E tū (2018) The proposed equal pay settlement - What you need to know. Accessed 23 September 2019 at: https://www.psa.org.nz/assets/Uploads/Equal-pay-handout-PSA-Etu2018.pdf.

Public Service Association [PSA] and E tū (2019) PSA and E tū submission to the Health Select Committee on Support Workers (Pay Equity)

Settlements Amendment Bill, 15 July 2019. Accessed 20 October 2019 at: https://www.psa.org.nz/dmsdocument/224920.

Rubery J (2018) Joan Acker and doing comparable worth. Gender, Work \& Organization, 1-8. DOI: 10.1111/gwao.12242

Rubery J and Koukiadaki A (2018) Institutional Interactions in Gender Pay Equity: A Call for Inclusive, Equal and Transparent Labour Markets. University of Oxford Human Rights Hub Journal, 1, 115-142.

Stuff (2009) 'Gagged women's family wants her to stay in rest home', January 31, 2009. Accessed 25 September 2019 at:

http://www.stuff.co.nz/national/politics/510933/Gagged-womansfamily-wants-her-to-stay-in-rest-home,

Tattersall A (2006) Bringing the community in: possibilities for public sector union success through community unionism. International Journal of Human Resources Development and Management, 6(2-4), 186-199.

Tattersall A (2008) Coalitions and Community Unions. Journal of Organizational Change Management, 21(4), 415-32.

Tattersall A (2010) Power in Coalition - Strategies for Strong Unions and Social Change. Allen and Unwin, Crows Nest.

Tattersall A (2018) How do we build power in coalition? Rethinking unioncommunity coalition types 12 years on. Labour \& Industry: a journal of the social and economic relations of work, 28(1), 68-81.

Walby S (2005a) Measuring women's progress in a global era. International Social Science Journal, 57(184), 371-387.

Walby S (2005b) Gender mainstreaming: Productive tensions in theory and practice. Social Politics: International Studies in Gender, State \& Society, 12(3), 321-343.

Williams F (2012) Converging variations in migrant care work in Europe Journal of European Social Policy, 22(4), 363-376.

Wilson M (1992) Employment Equity Act 1990: A case study in women's political influence 1984-90' pp 113-131 in Deeks J \& Perry N (eds) Controlling interests: Business, the state and society in New Zealand, Auckland University Press, Auckland. 
Zajak, S., Gortanutti, G., Lauber, J., and Nikolas, A. M. (2018) Talking about the same but different? Understanding social movement and trade union cooperation through social movement and industrial relations theories Industrielle Beziehungen, 2, 166-187.

Case List

Service and Food Workers Union Nga Ringa tota Inc $v$ Terranova Homes and Care Ltd [2013] NZELR 78.

Terranvova Homes \& Care Ltd v Service and Food Workers Union Nga Ringa Tota Inc [2014] NZCA 516.

Healthcare Providers New Zealand Incorporated and Anor v DHBs [2017] HC WN CIV-2007-485-1814.

Idea Services Ltd v Dickson [2011] NZCA 14.

Queensland Services Industrial Union of Employees and Queensland Chamber of Commerce and Industry Ltd, Industrial Organisation of Employers' [2009] 191 (2) QGIG 19.

Equal Remuneration Case [2012] 208 IR 446

Other material used

John Ryall: Undated affidavit prepared in preparation for appeal of Terranova 2014 decision.

Interviews with:

- John Ryall, E tū, 13 December 2016.

- Official, New Zealand Home \& Community Health Association, 29 November 2016.

- $\quad$ Official, Public Services Association, 17 October 2016. 